Sex Work and the City 
Inter-America Series

Duncan Earle, Howard Campbell, and John Peterson, editors

In the new "Inter-American" epoch to come, our borderland zones may expand well past the confines of geopolitical lines. Social knowledge of these dynamic interfaces offers rich insights into the pressing and complex issues that affect both the borderlands and beyond. The Inter-America Series comprises a wide interdisciplinary range of cutting-edge books that explicitly or implicitly enlist border issues to discuss larger concepts, perspectives, and theories from the "borderland" vantage and will be appropriate for the classroom, the library, and the wider reading public. 


\section{Sex Work and the City}

The Social Geography of Health and Safety in Tijuana, Mexico

YASMINA KATSULIS

University of Texas Press $\boldsymbol{\sim}$ Austin 
Copyright (C) 2008 by the University of Texas Press

All rights reserved

Printed in the United States of America

First edition, 2008

Requests for permission to reproduce material from this work should be sent to:

Permissions

University of Texas Press

P.O. Box 7819

Austin, TX 78713-7819

www.utexas.edu/utpress/about/bpermission.html

@ The paper used in this book meets the minimum requirements of ANSI/Niso Z39.48-I992 (RI997) (Permanence of Paper).

\section{Library of Congress Cataloging-in-Publication Data}

Katsulis, Yasmina, I972-

Sex work and the city : the social geography of health and safety in Tijuana, Mexico / Yasmina Katsulis. - Ist ed.

p. $\quad \mathrm{cm}$. - Inter-America Series, Duncan Earle, Howard Campbell, and John Peterson series editors

Includes bibliographical references and index.

Is BN 978-0-292-71886-9 (cloth : alk. paper)

I. Prostitution-Mexico-Tijuana. 2. Prostitutes-Mexico-Tijuana.

I. Title. II. Series.

HQI5I.T54K37 2008

$306.740972^{\prime} 23-\mathrm{dc} 22$ 
For Jeff, who supports me in all things that matter. 
THIS PAGE INTENTIONALLY LEFT BLANK 